\title{
Effect of Diet Supplementation with Food Industry By-Products on Diabetic Rats
}

\author{
Sirekhatim B. Elhardallou1 ${ }^{*}$, Wisal A. M. Babiker², Abdel Moneim E. Sulieman², \\ Adil Abdalla Gobouri ${ }^{1}$ \\ ${ }^{1}$ Department of Chemistry, Faculty of Science, University of Taif, Taif, Kingdom of Saudi Arabia \\ ${ }^{2}$ Faculty of Applied Medical Sciences, University of Taif, Taif, Kingdom of Saudi Arabia \\ ${ }^{3}$ Department of Biology, Faculty of Science, University of Hail, Hail, Kingdom of Saudi Arabia \\ Email: "drhardallou@yahoo.com
}

Received 11 May 2015; accepted 21 July 2015; published 24 July 2015

Copyright (C) 2015 by authors and Scientific Research Publishing Inc.

This work is licensed under the Creative Commons Attribution International License (CC BY).

http://creativecommons.org/licenses/by/4.0/

(c) (i) Open Access

\begin{abstract}
The present research work aimed to study the effects of 3 nutritional food industry by-products (orange peels, peanut skin peels and pomegranate peel) on regulating blood glucose level. 66 male adult Sprague-Dawely rats weighing $125 \pm 5 \mathrm{~g}$ each were used. These rats were injected with alloxan for inducing diabetes. The negative control group consisted of rats fed on basal diet, while the positive control group consisted of (3 - 11) sub-groups fed on basal diet in addition to $5 \%, 7.5 \%$ and $10 \%$ of nutritional food industry by-products. After 4 weeks the effect of the different experimental diets on body weight gain, organs relative weight, blood glucose level, liver functions and kidney functions was recorded for the negative group and all the positive sub-groups. The results revealed that there was non-significant difference between all relative organ weights of liver, kidney and pancreas compared to control negative. Blood glucose level significantly decreased in all sub-groups compared to the control positive group.
\end{abstract}

\section{Keywords}

Glucose, Orange Peels, Peanut Skin Peels, Body Weight

\section{Introduction}

Food processing products have become an important sanitary problem to be studied. At present, efforts have been made for converting refused materials into valuable products [1]. On the other hand, food production is failing behind population growth in many developing countries. It is the vulnerable groups, particularly infants and young

\footnotetext{
${ }^{*}$ Corresponding author.
}

How to cite this paper: Elhardallou, S.B., Babiker, W.A.M., Sulieman, A.M.E. and Gobouri, A.A. (2015) Effect of Diet Supplementation with Food Industry By-Products on Diabetic Rats. Food and Nutrition Sciences, 6, $875-882$. 
children of low income sectors, who suffer most. The result is high mortality rate, morbidity and prevalent malnutrition [2]. There are some food processing wastes such as pomegranate peel, orange peel and peanuts skin (Arachis hypogae L); which are considered important factors of therapeutic diets, supplying essential nutrient elements such as fiber, vitamin, and minerals to human body.

The term Diabetes mellitus is used to describe a group of conditions characterized by raised blood glucose levels (hyperglycemia) [3]. It is a chronic disorder caused by an absolute deficiency of insulin [4].

It has been reported that only water-soluble fiber is active on plasma glucose and lipoprotein metabolism in humans. Therefore, in practice, the consumption of legumes, vegetables, and fruits-rich in water-soluble fibershould be particularly encouraged. The mechanisms by which dietary fiber exerts its hypoglycemic and hypolipidemic activities are unknown. However, the ability of dietary fiber to retard food digestion and nutrient absorption certainly has an important influence on lipid and carbohydrate metabolism [5]. The beneficial effects of high-fiber foods are also exerted by some foods not particularly rich in fiber. The fiber content and physical form of the food can influence the accessibility of nutrients by digestive enzymes, thus delaying digestion and absorption. The identification of these foods with a low-glycemic response would help enlarge the list of foods particularly suitable for diabetic patients.

The important role of dietary fiber in the treatment of diabetic patients was indicated by the pioneer studies of Kiehm et al. [6], who showed a drastic reduction of the insulin dosage and a dramatic improvement of blood glucose control in insulin-treated diabetic patients by prescribing a high-carbohydrate/high-fiber diet.

Orange peels are the thick finely-textured and orange coloured skin of oranges. Since ancient times, orange peels have been valued for their curative properties. Many highly nutritious compounds of oranges are found in the peels. Almost all the anti-cholesterol compounds in oranges are found in the peels. These compounds help combat the LDL or "bad" cholesterol in our bodies that form clots and plaque culminating in clogged heart arteries. Therefore, including orange peels to your diet can lower the total cholesterol levels in the body [7].

Peanuts are composed of a thick, outer shell and, when cracked open, have a nut or seed encased by a thin, papery skin. The shell and skin are often thrown out, as the nut is the tasty portion of the product. However, the skin has beneficial properties. Peanut skin extract is now a product that consumers can buy, but some peanut lovers eat the skin as part of the treat, and some peanut butters actually use the skin when producing the item [8].

Pomegranate peels are gaining popularity for many reasons when it comes to the fantastic health benefits they can provide. There are several uses for pomegranate peels, the peels have great potential as a supplement to our health. The peels of a pomegranate fruit contain double the antioxidants that the pulp contains, they are possibly effective against prostate cancer, diabetes, and lymphoma disease. They can maintain the correct blood pressure and they are helpful in dealing with fertility problems beside many other health benefits [9].

The present study aimed to investigate the effect of the food industry by-products (orange peels, peanut skin peels and pomegranate peel on the blood glucose levels in diabetic rats.

\section{Materials and Methods}

\subsection{Samples}

The materials used for the current study were three food industry by-products namely orange (Citrus sinenis) peels, peanut (Arachis hypogaea L) skin peels and pomegranate (Punica granatum) peels. The peels were brought form the local market, well washed and dried at $63^{\circ} \mathrm{C}$ using a fan oven. They were then processed into fine powder.

\subsection{Experimental Animals}

Sixty-six male albino rats were purchased from the Research Institute of Ophthalmology, Giza, Egypt with average weight (125 $\pm 5 \mathrm{~g})$ to be used for the biological evaluation. Each rat was housed in a special cage under controlled conditions. The animals were observed daily for the apparent signs such as shape, color and distribution of hair and physical activity. All rats were fed for 3 days on the standard diet for adaptation before the beginning of the experiment. Body weighed for each rat was recorded at the beginning of the experiment and once a week, and at the end of experimental period (4 weeks) each rat was weighed at the beginning of the experiment 3 days to determine the initial weight, weight once a week for 4 weeks. The diet presented to rats in special covered cups to avoid food loss. All rats were provided with water by glass tubes through wire cage and fed as needed throughout the experimental period. The relative organs weight will be calculated. 


\subsection{Preparation of Diabetic Rats}

Sixty rats were injected with $150 \mathrm{mg} / \mathrm{kg}$ body weight of re-crystallized alloxan to induce hyperglycemia, after fasting overnight according to Buko et al. [10]. After six hours of the injection of alloxan, blood samples were obtained by retro orbital method to estimate the rate of serum glucose. Rats having fasting serum glucose 190 $\mathrm{mg} / \mathrm{dl}$ were considered diabetic according to Nakatsu et al. [11].

\subsection{Experimental Diet}

The composition of basal diet and experimental diets per $100 \mathrm{~g}$ for normal and diabetic rats contained $12 \mathrm{~g}$ casein, $10 \mathrm{~g}$ corn oil, $4 \mathrm{~g}$ salt mix, $1 \mathrm{~g}$ vitamin mix, $0.2 \mathrm{~g}$ Calcium chloride and $7.8 \mathrm{~g}$ corn starch. The experimental diets contained in addition 5\%, $7.5 \%$ and $10 \%$ orange peels, peanut peels and pomegranate peels.

\subsection{Grouping of Experimental Animals}

Rats were divided into 11 groups, 6 rats in each group and fed with experimental diets for consecutive 28 days as follows:

Group 1 Normal rats, were fed on basal diet as negative control (-).

Group 2 Diabetic rats, were fed on basal diet as positive control (+).

Group 3 Diabetic rats, were fed on basal diet supplemented with 5\% orange peel powder.

Group 4 Diabetic rats, were fed on basal diet supplemented with 5\% peanut peel powder.

Group 5 Diabetic rats, were fed on basal diet supplemented with 5\% Pomegranate peel powder

Group 6 Diabetic rats, were fed on basal diet supplemented with 7\% orange peel powder.

Group 7 Diabetic rats, were fed on basal diet supplemented with 7\% peanut peel powder.

Group 8 Diabetic rats, were fed on basal diet supplemented with 7\% Pomegranate peel powder

Group 9 Diabetic rats, were fed on basal diet supplemented with $10 \%$ orange peel powder.

Group 10 Diabetic rats, were fed on basal diet supplemented with $10 \%$ peanut peel powder.

Group 11 Diabetic rats, were fed on basal diet supplemented with 10\% Pomegranate peel powder.

\subsection{Blood Sampling}

At the end of the experiment, rats were fasted for overnight (more than 12 hours) and anesthetized with chloroform. Blood samples were collected in clean dry centrifuge tubes from hepatic portal vein and centrifuged for $10 \mathrm{mi}-$ nutes at $3000 \mathrm{rpm}$ to separate the serum, which was kept in tubes at $-18^{\circ} \mathrm{C}$ till analysis.

\section{Organs Weight}

Liver, pancreas, spleen and kidneys of the experimental rats were carefully removed, washed in saline solution, dried and weighed. The relative organs' weights were calculated according to the method described by Champman et al. [12] using the following equation:

$$
\begin{aligned}
& \text { Relative organa weight (ROW) } \\
& =\frac{\text { organ weight }(\mathrm{g})}{\text { final body weight }(\mathrm{g})} \times 100
\end{aligned}
$$

\subsection{Determination of Blood Glucose Levels}

Blood and liver glucose levels were determined by the method of Trinder [13], using Stanbio enzymatic glucose procedure in which glucose is oxidized in presence of glucose oxidase (GO). The hydrogen peroxide formed reacts under influence of peroxidase (PO), with P-hydroxybenzene (P-HBS) and 4-aminoantipyrine to from a redviolet quinone complex. The intensity of the color is proportional to glucose concentration.

$$
\begin{gathered}
\text { Glucose }+\mathrm{O}_{2}+\mathrm{H}_{2} \mathrm{O} \stackrel{\text { GO }}{\longrightarrow} \text { Gluconic acid }+\mathrm{H}_{2} \mathrm{O}_{2} \\
\mathrm{H}_{2} \mathrm{O}_{2}+\text { 4-amino-antipyrine }+ \text { p-HBS } \stackrel{\text { PO }}{\longrightarrow} \text { Quinone complex }
\end{gathered}
$$




\subsection{Liver Function Tests}

\subsubsection{Determination of GOT (AST) Glutamic- Oxaloacetic Transaminase}

Colorimetric method was used to determine AST according to Reitman and Frankel [14]. In which the oxaloacetate and/or pyruvate formed in either the GOT or GPT reaction is combined with 2, 4-dinitrophenylhydrazine to yield a brown-coloured hydrazone which is measured at $505 \mathrm{m \mu}$. in the photometer.

\subsubsection{Determination of Glutamic-Pyruvic Transaminase (GPT)}

Colorimetric method was used to determine ALT according to Reitman and Frankel [14]. Optical density readings were made using a Beckman DB spectrophotometer. The cuvette compartment of this instrument was fitted with thermo spacers to allow temperature control of the compartment within $\pm 0.5^{\circ} \mathrm{C}$ from a thermostatically controlled circulating bath. Careful timing of the readings during the enzyme reaction was observed in all the studies.

\subsection{Kidney Function Tests}

\subsubsection{Determination of Urea}

Urea was determined according to the method by Fawcett and Soctt [15], which is based on the following reaction:

$$
\text { Urea }+\mathrm{H}_{2} \mathrm{O} \stackrel{\text { Urease }}{\longrightarrow} 2 \mathrm{NH}_{3}+\mathrm{CO}_{2} \text { Does Argan }
$$

The ammonium ions formed will be measured by the Berthelot reaction. The blue dye indophenols product reaction absorbs light between $530 \mathrm{~nm}$ and $560 \mathrm{~nm}$ proportional to initial urea concentration. The various reagents were mixed, incubated for $15 \mathrm{~min}$. at $37^{\circ} \mathrm{C}$ was measured the absorbance of the sample $\left(\mathrm{A}_{\text {sample }}\right)$ and of the standard $\left(\mathrm{A}_{\text {standard }}\right)$ against the blank at $550 \mathrm{~nm}(530-570 \mathrm{~nm})$. Color was stable for 5 hours. Linearity up to $200 \mathrm{mg} / \mathrm{dl}$ (33.3 $\mathrm{mmol} / \mathrm{L})$ in serum or plasma and $4 \mathrm{~g} / \mathrm{dl}(665 \mathrm{mmol} / \mathrm{L})$ in urine. Urea was calculated according to the following formula:

$$
\begin{gathered}
\text { Urea concentration }=\frac{A_{\text {sample }}}{A_{\text {standard }}} \times \text { Standard concentration } \\
\text { Urea in Urine }(\mathrm{g} / \mathrm{dl})=\frac{A_{\text {sample }}}{A_{\text {standard }}} \times 3
\end{gathered}
$$

\subsubsection{Determination of Creatinine}

Colorimetric method was used to determine creatinine according to Barties and Bohmer [16]; In which creatinine in alkaline solution reacts with picric acid to form a colored complex the amount of the complex formed is directly proportional to the creatinine concentration. The reagents were mixed and after 20 seconds at $20^{\circ} \mathrm{C}-25^{\circ} \mathrm{C}$ readied the absorbance $A_{1}$ of the standard and sample at $495 \mathrm{~nm}(490-510 \mathrm{~nm})$ against distilled water, used cuvettes $1 \mathrm{~cm}$ light path. Exactly 2 minutes later, read absorbance $A_{2}$ of sample and standard. Linearity was up to $10 \mathrm{mg} / \mathrm{dl}$ in serum or plasma and $500 \mathrm{mg} / \mathrm{dl}$ in diluted urine. Creatinine was calculated as follows:

$$
\begin{gathered}
\mathrm{A}_{2}-\mathrm{A}_{1}=\Delta \mathrm{A}_{\text {sample }} \quad \text { or } \quad \Delta \mathrm{A}_{\text {standard }} \\
\text { Creatinine in serum }(\mathrm{mg} / \mathrm{dl})=\frac{\Delta \mathrm{A}_{\text {sample }}}{\Delta \mathrm{A}_{\text {standard }}} \times 2 \\
\text { Creatinine in urine }(\mathrm{mg} / \mathrm{dl})=\frac{\Delta \mathrm{A}_{\text {sample }}}{\Delta \mathrm{A}_{\text {standard }}} \times 100
\end{gathered}
$$

\subsection{Determination of Uric Acid}

Colorimetric method was used to determine uric acid according to the method by Caraway [17]. In which, uric acid reduces phosphotungstic acid in alkaline medium, producing a blue complex. The intensity of the blue color is in proportion to the uric acid concentration. The reagents were mixed. Incubated for $5 \mathrm{~min}$ at $37^{\circ} \mathrm{C}$ or $30 \mathrm{~min}$ at room temp. Readied the absorbance of the sample $\left(\mathrm{A}_{\text {sample }}\right)$ and of the standard $\left(\mathrm{A}_{\text {standard }}\right)$ against the blank at 700 
$\mathrm{nm}(680-720 \mathrm{~nm})$. Concentration of uric acid in serum (mg/dl) was calculated as follows:

Concentration of uric acid in serum (mg/dl)

$$
\frac{A_{\text {sample }}}{A_{\text {standard }}} \times 10
$$

\section{Results and Discussion}

\subsection{Effect of Studied Peels Feeding on Organs Weight of Diabetic Rats}

As presented in Table 1, a gradual increase of relative liver weight was observed with the increase of supplement level. Rats fed control diet showed relative kidney weight level $1.28 \% \pm 0.04 \% \mathrm{~g} / \mathrm{l00g}$. Rats fed orange peel supplement at levels $5 \%, 7.5 \%$ and $10 \%$ presented average kidney weight levels of $1.33 \% \pm 0.02 \%, 1.40 \% \pm 0.02 \%$ and $1.48 \% \pm 0.0 \mathrm{~g} / \mathrm{l00g}$, respectively. The relative kidney weight were $1.37 \% \pm 0.03 \%, 1.44 \% \pm 0.06 \%$ and $1.54 \%$ $\pm 0.03 \% \mathrm{~g} / \operatorname{lo0gm}$ for peanut peels feeding levels $5 \%, 7.5 \%$ and $10 \%$, respectively. The kidney weight of rats fed diet supplemented with pomegranate peel at levels $5 \%, 7.5 \%$ and $10 \%$ were $1.43 \% \pm 0.01 \%, 1.47 \% \pm 0.02 \%$ and

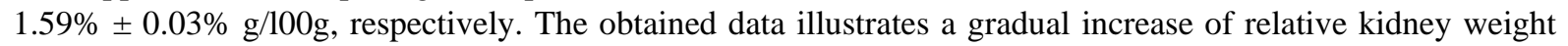
when orange peel, peanut peels or pomegranate peel level increased.

Relative spleen weight level was $0.41 \% \pm 0.02 \% \mathrm{~g} / \mathrm{l00g}$ in control group. The weight levels $0.43 \% \pm 0.01 \%$, $0.46 \% \pm 0.01 \%$ and $0.48 \% \pm 0.02 \%$ were recorded for levels $5 \%, 7.5 \%, 10 \%$ of orange peel supplement, respectively. Rats fed diet supplemented with peanut skin at levels $5 \%$ and $7.5 \%, 10 \%$ presented the weight levels $0.45 \pm$ $0.030 .48 \pm 0.01$ and $0.53 \% \pm 0.02 \%$ g/l00g, respectively. Pomegranate peel feeding levels 5\%, 7.5\% and 10\% presented the weight levels $0.45 \%+0.02 \%, 0.52 \%+0.03 \%$ and $0.62 \%+0.01 \% \mathrm{~g} / \mathrm{l00 \textrm {g }}$, respectively a gradual increase in relative spleen weight was observed when orange peel, peanut skin or pomegranate peel level increased. It has been reported that few clinical trials have demonstrated that the intake of dietary fibre has a positive effect on the control of diabetes and body weight [18].

\subsection{The Effect of Studied Peels Feeding on Liver Function of Diabetic Rats}

Table 2 shows the effect of feeding different levels of orange peel, peanut skin or pomegranate peel on liver functions in alloxan-induced diabetic rats. Aspartate aminotranspherase (AST) level in rats fed control diet was $32.1 \pm 0.10 \mathrm{U} / \mathrm{L}$. Regarding orange peel feed levels 5\%, 7.5\% and 10\%, Aspartate aminotranspherase (AST) levels were $30.1 \pm 0.10,27.1 \pm 0.11,24.1 \pm 0.35 \mathrm{U} / \mathrm{L}$, respectively. Rats fed diet supplemented with peanut skin at levels 5, 7.5 and 10\% recorded the levels $29.3 \pm 0.35,26.1 \pm 0.20$ and $23.1 \pm 0.20 \mathrm{U} / \mathrm{L}$, respectively. Aspartate aminotranspherase (AST) levels in rats fed pomegranate peel supplemented diet were 27.1 $\pm 0.22,23.4 \pm 0.10$ and $21.3+0.30 \mathrm{U} / \mathrm{L}$ at levels 5, 7.5 and 10\%, respectively. Observing the table we can see the gradual decrease of Aspartate aminotranspherase (AST) levels with the elevation of the supplement level.

Rats fed control diet represented Alanine aminotranspherase (ALT) level $29.4 \pm 2.50 \mathrm{U} / \mathrm{L}$. Regarding orange peel feed levels 5\%, 7.5\% and 10\%, Alanine aminotranspherase (ALT) levels were $26.4 \pm 2.01,24.8 \pm 2.20$ and $22.1 \pm 2.10 \mathrm{U} / \mathrm{L}$, respectively. Rats fed diet supplemented with peanut skin at levels 5\%, $7.5 \%$ and $10 \%$ showed the levels $25.3 \pm 4.16,22.8 \pm 1.12$ and $19.4 \pm 2.11 \mathrm{U} I \mathrm{~L}$, respectively. Alanine aminotranspherase (ALT) levels

Table 1. Effect of feeding different levels of orange peels, peanut skin and pomegranate peel on relative weight of the organs in alloxan- induced diabetic rats.

\begin{tabular}{|c|c|c|c|c|c|c|c|c|c|c|}
\hline \multirow{2}{*}{ Parameter } & \multirow{2}{*}{$\begin{array}{l}\text { Control } \\
\text { Group }\end{array}$} & \multicolumn{3}{|c|}{ Orange peel feed level } & \multicolumn{3}{|c|}{ Peanut skin feed level } & \multicolumn{3}{|c|}{ Pomegranate peel feed level } \\
\hline & & $5 \%$ & $7.5 \%$ & $10 \%$ & $5 \%$ & $7.5 \%$ & $10 \%$ & $5 \%$ & $7.5 \%$ & $10 \%$ \\
\hline $\begin{array}{l}\mathrm{LW} / \mathrm{BW} \\
\text { (g/100g) }\end{array}$ & $\begin{array}{l}2.3 \pm \\
0.01^{\mathrm{a}}\end{array}$ & $2.43 \pm 0.02^{\mathrm{a}}$ & $\begin{array}{c}2.48 \pm \\
0.03^{\mathrm{a}}\end{array}$ & $\begin{array}{c}2.53 \pm \\
0.02^{b}\end{array}$ & $\begin{array}{c}2.46 \pm \\
0.01^{\mathrm{a}}\end{array}$ & $\begin{array}{c}2.52 \pm \\
0.01^{b}\end{array}$ & $\begin{array}{c}2.57 \pm \\
0.01^{\mathrm{b}}\end{array}$ & $\begin{array}{c}2.52 \pm \\
0.03^{b}\end{array}$ & $\begin{array}{c}2.64 \pm \\
0.02^{c}\end{array}$ & $\begin{array}{c}2.73 \pm \\
0.02^{\mathrm{d}}\end{array}$ \\
\hline $\begin{array}{l}\text { KW/BW } \\
\text { (g/100g) }\end{array}$ & $\begin{array}{c}1.28 \pm \\
0.04^{\mathrm{a}}\end{array}$ & $\begin{array}{c}1.33 \pm \\
0.02^{\mathrm{b}}\end{array}$ & $\begin{array}{c}1.40 \pm \\
0.02^{\mathrm{b}}\end{array}$ & $\begin{array}{c}1.48 \pm \\
0.01^{b}\end{array}$ & $\begin{array}{c}1.37 \pm \\
0.03^{\mathrm{a}}\end{array}$ & $\begin{array}{c}1.44 \pm \\
0.06^{\mathrm{b}}\end{array}$ & $\begin{array}{c}1.54 \pm \\
0.03^{\mathrm{c}}\end{array}$ & $\begin{array}{c}1.43 \pm \\
0.01^{\mathrm{b}}\end{array}$ & $\begin{array}{c}1.47 \pm \\
0.02^{b}\end{array}$ & $\begin{array}{c}1.59 \pm \\
0.03^{\mathrm{e}}\end{array}$ \\
\hline $\begin{array}{l}\text { SW/BW } \\
\text { (g/100g) }\end{array}$ & $\begin{array}{c}0.41 \pm \\
0.02^{\mathrm{a}}\end{array}$ & $\begin{array}{c}0.43 \pm \\
0.01^{\mathrm{a}}\end{array}$ & $\begin{array}{c}0.46 \pm \\
0.01^{\mathrm{a}}\end{array}$ & $\begin{array}{c}0.48 \pm \\
0.02^{\mathrm{b}}\end{array}$ & $\begin{array}{c}0.45 \pm \\
0.03^{\mathrm{a}}\end{array}$ & $\begin{array}{c}0.48 \pm \\
0.01^{\mathrm{b}}\end{array}$ & $\begin{array}{c}0.45 \pm \\
0.02^{\mathrm{a}}\end{array}$ & $\begin{array}{c}0.53 \pm \\
0.02^{\mathrm{b}}\end{array}$ & $\begin{array}{c}0.52 \pm \\
0.03^{\mathrm{b}}\end{array}$ & $\begin{array}{c}0.62 \pm \\
0.01^{\mathrm{c}}\end{array}$ \\
\hline
\end{tabular}

LW: Liver Weight; KW: Kidney weight; SW: Spleen Weight; BW: Body Weight. " Mean \pm SE; Different letters on the numbers mean significant differences at $\mathrm{P}<0.05$. 
Table 2. Effect of feeding different levels of orange peels, peanut skin or pomegranate peel on liver functions; in alloxaninduced diabetic rats.

\begin{tabular}{|c|c|c|c|c|c|c|c|c|c|c|}
\hline \multirow{2}{*}{ Parameter } & \multirow{2}{*}{$\begin{array}{l}\text { Control } \\
\text { Group }\end{array}$} & \multicolumn{3}{|c|}{ Orange peel feed level } & \multicolumn{3}{|c|}{ Peanut skin peel feed level } & \multicolumn{3}{|c|}{ Pomegranate peel feed level } \\
\hline & & $5 \%$ & $7.5 \%$ & $10 \%$ & $5 \%$ & $7.5 \%$ & $10 \%$ & $5 \%$ & $7.5 \%$ & $10 \%$ \\
\hline AST(U/L) & $\begin{array}{c}32.1 \pm \\
0.10^{\mathrm{a}}\end{array}$ & $\begin{array}{c}30.1 \pm \\
0.10^{\mathrm{a}}\end{array}$ & $\begin{array}{c}27.1 \pm \\
0.11^{b}\end{array}$ & $\begin{array}{c}24.1 \pm \\
0.35^{b}\end{array}$ & $\begin{array}{c}29.3 \pm \\
0.35^{b}\end{array}$ & $\begin{array}{c}26.1 \pm \\
0.20^{\mathrm{b}}\end{array}$ & $\begin{array}{c}23.1 \pm \\
0.20^{c}\end{array}$ & $\begin{array}{c}27.1 \pm \\
0.22^{\mathrm{b}}\end{array}$ & $\begin{array}{c}23.4 \pm \\
0.10^{\mathrm{b}}\end{array}$ & $\begin{array}{c}21.3 \pm \\
0.30^{c}\end{array}$ \\
\hline ALT(U/L) & $\begin{array}{c}29.4 \pm \\
2.50^{\mathrm{a}}\end{array}$ & $\begin{array}{c}26.4 \pm \\
2.01^{b}\end{array}$ & $\begin{array}{c}24.8 \pm \\
2.20^{\mathrm{b}}\end{array}$ & $\begin{array}{c}22.1 \pm \\
2.10^{c}\end{array}$ & $\begin{array}{l}25.3 \pm \\
4.16^{\mathrm{ab}}\end{array}$ & $\begin{array}{c}22.8 \pm \\
1.12^{\mathrm{c}}\end{array}$ & $\begin{array}{c}19.4 \pm \\
2.11^{\mathrm{c}}\end{array}$ & $\begin{array}{c}24.0 \pm \\
2.52^{\mathrm{a}}\end{array}$ & $\begin{array}{c}21.8 \pm \\
3.25^{\mathrm{b}}\end{array}$ & $\begin{array}{c}17.3 \pm \\
1.10^{c}\end{array}$ \\
\hline $\mathrm{ALP}(\mathrm{U} / \mathrm{L})$ & $\begin{array}{c}96.4 \pm \\
2.51^{\mathrm{a}}\end{array}$ & $\begin{array}{c}88.1 \pm \\
2.05^{b}\end{array}$ & $\begin{array}{c}83.1 \pm \\
2.10^{b}\end{array}$ & $\begin{array}{c}79.1 \pm \\
2.30^{\mathrm{c}}\end{array}$ & $\begin{array}{c}85.1 \pm \\
1.10^{\mathrm{b}}\end{array}$ & $\begin{array}{c}82.1 \pm \\
1.40^{\mathrm{b}}\end{array}$ & $\begin{array}{c}75.1 \pm \\
2.03^{\mathrm{c}}\end{array}$ & $\begin{array}{c}783.1 \pm \\
1.40^{\mathrm{a}}\end{array}$ & $\begin{array}{c}79.1 \pm \\
1.25^{\mathrm{b}}\end{array}$ & $\begin{array}{c}73.1 \pm \\
1.10^{\mathrm{b}}\end{array}$ \\
\hline
\end{tabular}

AST: Aspartate aminotranspherase; ALT: Alanine aminotranspherase; (ALP): Alkalin phosphatase; ${ }^{*}$ Mean \pm SE; Different letters on the numbers mean significant differences at $\mathrm{P}<0.05$.

were $24.0 \pm$ 2.52, $21.8 \pm 3.25$ and $17.3 \pm 1.10 \mathrm{U} / \mathrm{L}$ when pomegranate peel feed levels were $5 \%, 7.5 \%$ and $10 \%$, respectively. Alanine aminotranspherase (ALT) levels decreased gradually when the supplement level increased, as the detected data show.

Rats fed control diet showed Alkalin phosphatase (ALP) level $96.4+2.51 \mathrm{U} / \mathrm{L}$. Alkalin phosphatase (ALP) levels were $88.1 \pm 2.05,83.1 \pm 2.10$ and $79.1 \pm 2.30$ UI, when orange peel feed levels were $5 \%, 7.5 \%$ and $10 \%$, respectively. Rats fed diet supplemented with peanut skin at levels 5\%, 7.5\% and 10\% showed the levels $85.1 \pm$ $1.10,82.1 \pm 1.40$ and $75.1 \pm 2.03 \mathrm{U} / \mathrm{L}$, respectively. When pomegranate peel feed levels were $5,7.5$ and $10 \%$ Alkalin phosphatase (ALP) levels were $83.1 \pm 1.40,79.1+1.25$ and $73.1+1.10 \mathrm{U} / \mathrm{L}$, respectively. Alkalin phosphatase (ALP) decreased markedly with the elevation of orange peel, peanut skin or pomegranate peel level in the diet. It has been reported that Consume high-quality dietary fibre: Enhance liver health with fibre, which binds to bile and eliminates fat-soluble toxins from the body [19].

\subsection{The Effect of Peels Feeding on Blood Glucose Level on Diabetic Rats}

Table 3 shows the effect of feeding different levels of orange peel, peanut peels and pomegranate peel on blood glucose level (mg/dl) in alloxan-induced diabetic rats. After a week of feeding control diet, the level was $392.7 \pm$ $3.5 \mathrm{mg} / \mathrm{dl}$. After feeding orange peel supplement in the diet at levels $5 \%, 7.5 \%$ and $10 \%$ for a week, blood glucose levels were $388.2 \pm 1.5,368.4 \pm 3.5$ and $305.2 \pm 5.5 \mathrm{mg} / \mathrm{dl}$, respectively. Rats fed diet supplemented with peanut peels at levels $5 \%, 7.5 \%$ and $10 \%$ presented the levels $372.2 \pm 2.1,352.2+2.5$ and $279.4 \pm 5.3 \mathrm{mg} / \mathrm{dl}$, respectively. Rats fed diet supplemented with pomegranate peel at levels 5\%, 7.5\% and $10 \%$ illustrated the levels 360.1 $+2.5,340.3 \pm 3.1$ and $226.2 \pm 2.1 \mathrm{mg} / \mathrm{dl}$, respectively. After a week of feeding, rats showed a gradual decrease of blood glucose level as the level of orange peel, peanut skin or pomegranate peel increased in the diet.

After 2 weeks, blood glucose level was $402.2 \pm 1.2 \mathrm{mg} / \mathrm{dl}$, for control group. Rats fed orange peel supplement in the diet at levels 5\%, 7.5\% and 10\% showed the levels $361.4 \pm 2.6,345.2+3.2$ and $288.4 \pm 3.3 \mathrm{mg} / \mathrm{dl}$, respectively. Rats fed diet supplemented with peanut skin at levels $5 \%, 7.5 \%$ and $10 \%$ showed the levels $355.3 \pm 3.5$, $334.2 \pm 3.0$ and $255.3 \pm 5.5 \mathrm{mg} / \mathrm{dl}$, respectively. Rats fed diet supplemented with pomegranate peel at levels 5\%, $7.5 \%$ and $10 \%$ showed the levels $342.2 \pm 4.0,314.4 \pm 2.3$ and $205.2 \pm 2.1 \mathrm{mg} / \mathrm{dl}$, respectively.

Blood glucose decreased gradually, after two weeks of feeding experimental supplements, with the increase of supplement level.

After 3 weeks of feeding control diet, blood glucose level was $368.3+3.5 \mathrm{mg} / \mathrm{dl}$. For orange peel feed levels $5 \%, 7.5 \%$ and $10 \%$ glucose levels were $327.2 \pm 5.5,313.5 \pm 3.6$ and $260.2 \pm 1.1 \mathrm{mg} / \mathrm{dl}$, respectively. Rats fed peanut skin supplement 5.75 and $10 \%$ in the diet presented the levels $318.2 \pm 2.6,288.5 \pm 1.0$ and $238.6 \pm 3.8$ $\mathrm{mg} / \mathrm{dl}$, respectively. Regarding pomegranate peel feed levels $5 \%, 7.5 \%$ and $10 \%$, it was observed that blood glucose levels were $286.5 \pm 3.2,270.5 \pm 5.5$ and $178.3+2.5 \mathrm{mg} / \mathrm{dl}$, respectively. Provided data illustrate a gradual decrease of blood glucose level as orange peel, peanut skin or pomegranate peel supplement level increased.

After feeding control diet for 4 weeks blood glucose level was $388.2 \pm 4.5 \mathrm{mg} / \mathrm{dl}$. Rats fed diet supplemented with orange peel, $5 \%, 7.5 \%$ and $10 \%$ showed levels $288.3 \pm 3.5,257.7 \pm 1.7$ and $218.5 \pm 3.5 \mathrm{mg} / \mathrm{dl}$, respectively. Rats fed diet supplemented with peanut skin, recorded levels $276.2 \pm 2.7,237.5 \pm 3.4$ and $200.6 \pm 1.5 \mathrm{mg} / \mathrm{dl}$ for levels $5 \%, 7.5 \%$ and $10 \%$, respectively. Rats fed diet supplemented with pomegranate peel $5 \%, 7.5 \%$ and $10 \%$, showed levels $236.3 \pm 1.2,227.2 \pm 1.2$ and $150.3 \pm 4.5 \mathrm{mg} / \mathrm{dl}$, respectively. Alter 4 weeks, blood glucose decreased 
Table 3. Effect of feeding different levels of orange peels, peanut skin or pomegranate peel on glucose level in alloxan-induced diabetic rats (units: $\mathrm{mg} / \mathrm{dl}$ ).

\begin{tabular}{|c|c|c|c|c|c|c|c|c|c|c|}
\hline \multirow{2}{*}{$\begin{array}{l}\text { Intervals } \\
\text { (weeks) }\end{array}$} & \multirow{2}{*}{$\begin{array}{l}\text { Control } \\
\text { Group }\end{array}$} & \multicolumn{3}{|c|}{ Orange peel feed level } & \multicolumn{3}{|c|}{ Peanut skin peel feed level } & \multicolumn{3}{|c|}{ Pomegranate peel feed level } \\
\hline & & $5 \%$ & $7.5 \%$ & $10 \%$ & $5 \%$ & $7.5 \%$ & $10 \%$ & $5 \%$ & $7.5 \%$ & $10 \%$ \\
\hline $\begin{array}{c}\text { First } \\
\text { Week }\end{array}$ & $392.7 \pm 3.5^{\mathrm{a}}$ & $388.2 \pm 1.5^{\mathrm{a}}$ & $368.4 \pm 3.5^{\mathrm{a}}$ & $\begin{array}{c}305.2 \pm \\
5.5^{b}\end{array}$ & $\begin{array}{c}372.2 \pm \\
2.1^{\mathrm{a}}\end{array}$ & $\begin{array}{c}352.2 \pm \\
2.5^{\mathrm{a}}\end{array}$ & $\begin{array}{c}276.4 \pm \\
5.3^{\mathrm{a}}\end{array}$ & $\begin{array}{c}360.1 \pm \\
2.5^{\mathrm{a}}\end{array}$ & $\begin{array}{c}340.3 \pm \\
3.1^{\mathrm{a}}\end{array}$ & $\begin{array}{c}226.2 \pm \\
2.1^{\mathrm{b}}\end{array}$ \\
\hline $\begin{array}{l}\text { Second } \\
\text { Week }\end{array}$ & $402.2 \pm 1.2^{\mathrm{a}}$ & $361.4 \pm 2.6^{\mathrm{a}}$ & $345.2 \pm 3.2^{b}$ & $\begin{array}{c}288.4 \pm \\
3.3^{b}\end{array}$ & $\begin{array}{c}355.3 \pm \\
3.5^{\mathrm{a}}\end{array}$ & $\begin{array}{c}334.2 \pm \\
3.0^{\mathrm{b}}\end{array}$ & $\begin{array}{c}255.3 \pm \\
5.5^{c}\end{array}$ & $\begin{array}{c}342.2 \pm \\
4.0^{\mathrm{b}}\end{array}$ & $\begin{array}{c}314.4 \pm \\
2.3^{\mathrm{b}}\end{array}$ & $\begin{array}{c}205.2 \pm \\
2.1^{\mathrm{c}}\end{array}$ \\
\hline $\begin{array}{l}\text { Third } \\
\text { Week }\end{array}$ & $368.3 \pm 2.7^{\mathrm{a}}$ & $327.2 \pm 5.5^{\mathrm{a}}$ & $313.5 \pm 3.6^{\mathrm{a}}$ & $\begin{array}{c}260.2 \pm \\
1.1^{\mathrm{b}}\end{array}$ & $\begin{array}{c}318.2 \pm \\
2.6^{\mathrm{a}}\end{array}$ & $\begin{array}{c}288.5 \pm \\
1.0^{\mathrm{b}}\end{array}$ & $\begin{array}{c}238.6 \pm \\
3.8^{\mathrm{b}}\end{array}$ & $\begin{array}{c}286.5 \pm \\
3.2^{\mathrm{b}}\end{array}$ & $\begin{array}{c}270.5 \pm \\
5.5^{b}\end{array}$ & $\begin{array}{c}178.3 \pm \\
2.5^{\mathrm{c}}\end{array}$ \\
\hline $\begin{array}{l}\text { Fourth } \\
\text { Week }\end{array}$ & $388.2 \pm 4.5^{\mathrm{a}}$ & $288.3 \pm 3.5^{b}$ & $257.7 \pm 1.7^{\mathrm{b}}$ & $\begin{array}{c}218.5 \pm \\
3.5^{b}\end{array}$ & $\begin{array}{c}276.2 \pm \\
2.7^{\mathrm{b}}\end{array}$ & $\begin{array}{c}237.5 \pm \\
3.4^{\mathrm{b}}\end{array}$ & $\begin{array}{c}200.6 .1 \pm \\
1.5^{c}\end{array}$ & $\begin{array}{c}236.3 \pm \\
1.2^{\mathrm{b}}\end{array}$ & $\begin{array}{c}227.2 \pm \\
1.2^{\mathrm{b}}\end{array}$ & $\begin{array}{c}150.3 \pm \\
4.5^{\mathrm{c}}\end{array}$ \\
\hline
\end{tabular}

${ }^{*}$ Mean \pm SE; Different letters on the numbers mean.

gradually with the increase of experimental supplement level.

There is much evidence that diabetic patients are at high risk of cardiovascular disease and that this risk increases in the presence of one or more of the other risk factors [20]-[22]. The important role of dietary fiber in the treatment of diabetic patients was indicated by the pioneer studies of Kiehm et al. [23], who showed a drastic reduction of the insulin dosage and a dramatic improvement of blood glucose control in insulin-treated diabetic patients by prescribing a high-carbohydrate/high-fiber diet.

\section{Conclusions}

The hypoglycemic properties of some food industry by-products such as pomegranate peel, peanut red hull and orange peels in this study may be attributed to one or more of its photochemical properties. The blood glucose level, liver function and kidney function were determined for the negative group and all sub-groups. The results obtained revealed that there was non-significant difference between all relative organ weights of liver, kidney and pancreas compared to control negative. Blood glucose level significantly decreased in all sub-groups compared to control positive.

The results indicated that pomegranate peel and peanut red hull can reduce blood glucose. It is highly recommended for the diabetic patients to include dietary fiber such as Pomegranate peel, peanut peel and orange peels in their diet.

\section{Acknowledgements}

The authors express their sincere gratitude to the staff member of the Department of Food Science and Technology of Gezira University, Sudan and the Research Institute of Ophthalmology, Giza, Egypt, and Department of Chemistry, Faculty of Science, Taif University, KSA; for the assistance presented by them.

\section{References}

[1] Mongeau, R. and Brassard, R. (1989) A Comparison of Three Methods for Analyzing Dietary Fiber in 38 Foods. Journal of Food Composition and Analysis, 2, 189-199. http://dx.doi.org/10.1016/0889-1575(89)90016-1

[2] Moussa, M., Limaee, N.Y, Mahmoodi, N.M. and Tabrizi, N.S. (1992) Fruits and Vegetables Contain a Variety of Antioxidant. Journal of Colloid and Interface Science, 288, 371-376.

[3] Rosenbloom, A.L. and Silverstein, J.H. (1998) Diabetes in Children and Adolescents: A Clinician's Guide to Diagnosis, Epidemiology, Pathogenesis, Prevention, and Treatment. American Diabetes Association, Alexandria, Virginia, 1.

[4] Vivian, M. (2006) Diabetes Mellitus: Is Differentiation into Insulin-Sensitive and Insulin-Insensitive Types. The Lancet, 227, 127-130.

[5] Gabriele, R. and Angela, R. (1991) Effects of Dietary Fiber and Carbohydrate on Glucose and Lipoprotein Metabolism in Diabetic Patients. Diabetic Care, 14, 1115-1125. http://dx.doi.org/10.2337/diacare.14.12.1115

[6] Kiehm, T.G,, Anderson, J.W. and Word, K. (1976) Beneficial Effects of a High-Carbohydrate, High Fiber Diet on Hyperglycemic Diabetic Men. The American Journal of Clinical Nutrition, 29, 895-899.

[7] http://healthmunsta.hubpages.com/hub/Benefits-of-Orange-Peels 
[8] http://www.livestrong.com/article/98722-nutrients-peanut-skins/

[9] Ismail, T., Sestili, P. and Akhtar, S. (2012) Pomegranate Peel and Fruit Extracts: A Review of Potential Anti-Inflammatory and Anti-Infective Effects. Journal of Ethnopharmacology, 143, 379-405.

[10] Buko, V., Lukivskaya, O., Nikitin, V., Tarasov, Y., Zavodnik, L., Borodinsky, A., Gorenshtein, B., et al. (1996) Hepatic and Pancreatic Effects of Polyenoylphosphatidylcholine in Rats with Alloxaninduced Diabetes. Cell Biochemistry and Function, 14, 131-137.

[11] Nakatsu, B.A., Abraham, A. and Leelamma, S. (1984) Antioxidant Effects of Some Plants in Rats Fed with High Fat Diet. Indian Journal of Experimental Biology, 35, 148-150.

[12] Champman, M.L., Vergara, J.M., Romero, A.L., Evickson, S.K. and Mc Namara, D.J. (1959) Gender Differences in Response to Dietary Soluble Fiber in Guinea Pigs: Effect of Pectin, Guar Gum and Psyllium. The Journal of Lipid Research, 36, 2191-2202.

[13] Trinder, D.M. (1969) Choline in the Nutrition of Chicks. The Journal of Biological Chemistry, 138, 459-470.

[14] Reitman, S. and Frankel, S. (1957) A Colorimetric Method for the Determination of Serum Glutamic Oxalacetic and Glutamic Pyruvic Transaminases. American Journal of Clinical Pathology, 28, 56-63.

[15] Bingham, S.A., Day, N.E., Luben, R., et al. (1960) Dietary Fiber in Food and Production against Cholesterol in the European Prospective Investigation into Cholesterol and Nutrition (EPIC): An Observational Study. The Lancet, 361, 1496-1499.

[16] Barties, S. and Bohmer, D. (1972) Epidemiology of Diabetes Interventions and Complications Study on the Use of Intensive Glycemic Treatment to Reduce the Risk of Complications of Type 1 Diabetes. Endocrine Practice, 12, 34-41.

[17] Caraway, H.M. (1995) The Effect of Some Fruit Peels on Serum Lipid. European Journal of Clinical Nutrition, 56, 1094-1101.

[18] Babio, N., Balanza, R., Basulto, J., Bulló, M. and Salas-Salvadó, J. (2010) Dietary Fibre: Influence on Body Weight, Glycemic Control and Plasma Cholesterol Profile. Nutricion Hospitalaria, 25, 327-340.

[19] King, B.J. (2005) Your Ultimate Guide to Abundant Energy. Health Venture Publications, Acton, ON. www.awakenyourbody.com

[20] Krowlewski, A.S., Warram, J.H., Rand, L.I. and Kahn, C.R. (1987) Epidemiologic Approach to the Etiology of Type I Diabetes Mellitus and Its Complications. The New England Journal of Medicine, 26, 1390-1398.

[21] Pyorala, K., Loast, M. and Uusitupa, M. (1987) Diabetes and Atherosclerosis: An Epidemiological View. Diabetes/ Metabolism Reviews, 3, 463-524. http://dx.doi.org/10.1002/dmr.5610030206

[22] Diabetes Drafting Group (1985) Prevalence of Small Vessel Disease and Large Vessel Disease in Diabetic Patients from 14 Centers: The WHO Multinational Study of Vascular Disease in Diabetics. Diabetologia, 28, 715-740.

[23] Kiehm, T.G., Anderson, J.W. and Word, K. (1976) Beneficial Effects of a High-Carbohydrate, High Fiber Diet on Hyperglycemic Diabetic Men. The American Journal of Clinical Nutrition, 29, 895-899. 